\title{
Effect of the Substrate and Containers in the Initial Growth of Seedlings of Physalis peruviana L.
}

\author{
J. G. Silva ${ }^{1}$, K. P. Lopes ${ }^{2}$, F. J. S. Paiva ${ }^{2}$, M. H. B. S. Rodrigues ${ }^{2} \&$ J. S. Nobrega ${ }^{3}$ \\ ${ }^{1}$ Faculdade de Agronomia Eliseu Maciel, Universidade Federal de Pelotas, Rio Grande do Sul, Brazil \\ ${ }^{2}$ Centro de Ciências e Tecnologia Agroalimentar, Universidade Federal de Campina Grande, Paraíba, Brazil \\ ${ }^{3}$ Universidade Federal da Paraíba, Areia, Brazil \\ Correspondence: J. G. Silva, Faculdade de Agronomia Eliseu Maciel, Universidade Federal de Pelotas, Av. Eliseu \\ Maciel, s/n-Capão Leão, Capão do Leão, Rio Grande do Sul 96050-500, Brazil. Tel: 55-(53)-981-404-384. E-mail: \\ joseano_agronomo@outlook.com
}

Received: April 24, 2018

doi:10.5539/jas.v10n8p314

\author{
Accepted: May 27, $2018 \quad$ Online Published: July 15, 2018 \\ URL: https://doi.org/10.5539/jas.v10n8p314
}

\begin{abstract}
Physalis peruviana L., from the family Solanaceae, is a fruitful species of high nutritional and economic value, incorporated in the category of the small fine fruits in Brazil, and is a promising source of income for small farmers, mainly in the Northeast area. This work aims to evaluate the influence of different substrate and containers in the initial growth of Physalis peruviana $\mathrm{L}$. The experiment was conducted in the greenhouse, in a completely randomized designing. Two types of containers (polypropylene seedling tray of 200 cells and containers of polypropylene of $50 \mathrm{~mL}$ ) and three compositions of the substrate (commercial substrate Hortiplant $^{\mathbb{R}}$, and ravine soil + sand + organic compost in the proportions $2: 1: 1$ and 2:1:2) were tested. The analyzed variables were: percentage of emergency and emergency velocity index of the plants; height of the plants; the number of leaves; length of the main root; and wet and dry mass of the root and the aerial part at the 30 days after sowing. Analyses of variance were used to test the effects of substrate and containers on the studied variables, and the averages of the studied variables were compared among treatments using the Tukey's test at $5 \%$ of probability. In the greenhouse conditions, Physalis peruviana L. seedlings grow better when sowed in the commercial substrate using the container of polypropylene of $50 \mathrm{~mL}$, resulting in larger seedlings, a larger number of leaves and a proper development of the root system.
\end{abstract}

Keyword: camapu, organic materials, production of seedlings

\section{Introduction}

The family Solanaceae presents plants that produce edible fruits of high nutritional value and great pharmacological importance due to the bioproduction of complex substances with several proven therapeutic properties (Lorenzi \& Bushes, 2008). Among the species of that family, the species Physalis peruviana L. is known popularly in Brazil as camapú, fisális or juá de capote. The P. peruviana L. has raised the interest of consumers and farmers due to the economic potential since it produces plenty attractive fruits, of good-looking coloration, sweet and sour flavor, rich in vitamins A and C, and substances with pharmacological activities, besides can be consumed as fresh fruit in the ornamentation of sweets or processed (Novoa, Bojacá, Galvis, \& Fischer, 2006; Fischer, Almanza-Merchán, \& Miranda, 2014).

The insertion of P. peruviana L. in the horticultural market is still very incipient, cultivated mainly in the South area of Brazil due to the appropriate climatic conditions. Although there are reports of its cultivation in the north and northeast area, there is no study, or there are few papers in the literature that mention its initial growth in climate conditions and altitude such as those of the northeast area (Lima, Galarça, Betemps, Rufato, \& Rufato, 2012; Rodrigues, Penoni, Soares, \& Pasqual, 2012).

The production cost is accessible to the small producers since it needs small areas and has a considerably high economic return (Lima, Gonçalves, Tomaz, Rufato, \& Fachinello, 2010a). Therefore, P. peruviana L. is seen as an excellent alternative to the small and medium rural producer (Rufato, Rufato, Schlemper, Lima, \& Kretzschmar, 2008). 
The production of seedlings is a fundamental practice for a good establishment of the culture in the field, minimizing the costs to the producer because of the smaller number of seeds used (Filgueira, 2013; Coelho et al., 2013). Consequently, it is possible to obtain a more substantial uniformity in the emergency and reduce the risks of pests and diseases in the initial phase. However, several factors can affect the growth of seedlings during the greenhouse phase such as the size of the container and the composition of the employed substrate, among others factors.

According to Pinto (2006), and Lima, Vilanova, Gonçalves, Rufato, and Rufato (2010b) the substrate is one of the primordial factors for the quality of seedlings, especially of fruitful species, propitiating good conditions for the growth of the embryo and the seedlings. The substrate has significant influence in the germinative process and should present a suitable structure, aeration, capacity of water retention, proper nutrition, the absence of infestation of diseases and pathogens, favoring the germination of the seeds and the excellent growth of the plants (Bardiviesso, Costa, Barcelos, \& Bardiviesso, 2014). Maciel, Rocha, Paro, Gioda, and Botrel (2007) highlighted the influence of the substrate in the architecture of the root system and in the biological associations with the environment, affecting the nutritional state of the plants and the translocation of water in the soil-plant-atmosphere system.

The choice of the substrate should be based on the needs of the plant to be cultivated, on the cultivation system, the physiochemical characteristics of the substrate, as well in the substrate availability. The commercial substrates are composed mainly of pinus peel, vermiculite, peats, coal ground, charred rice peel, and fiber of coconut peel. The use of products originated from rural properties can be an advantageous alternative for the formulation of a substrate for the farmer (Menezes Júnior, Fernandes, Mauch, \& Silva, 2000). According to Paiva, Maia, Cunha, Coelho, and Silva (2011), substrates of organic sources, such as the organic compost, are responsible for the largest moisture retention in the containers and supply most of the essential nutrients for the growth of the plants.

The definition of the size, height, and diameter of the container is a critical factors that influences several characteristics of the seedling and can impact the survival rate at the field and the productivity of the culture (Lima, Severino, Tomaz, Rufato, \& Fachinello, 2006). Thus, Viana, Gonçalvez, Andrade, Oliveira, and Silva (2008) reported the importance the dimension and volume of the containers for the production of seedlings, pointing out that larger containers than the needed results in unnecessary costs of the substrate.

The choice of the best container should consider the number of seedlings to be produced and the time that the seedlings stay in the nursery (Silva \& Stein, 2008). Containers of rigid walls can hold a small amount of substrate leading to deformations in the radicle system which reflect on the growth of the root and aerial part of the plant and persist in the field (Schiavo \& Martins, 2003). However, there is a balance point between the volume and the format of the container that allows a high-quality seedling and minimize the costs of production (Lima et al., 2006).

The present work aims to evaluate the emergency and the vegetative growth in plants of Physalis peruviana L. cultivated in different substrates and maintained in different containers during the phase of seedlings.

\section{Material and Methods}

\subsection{Location}

The work was conducted at the greenhouse of the Center for Agro-Food Science and Technology of the Federal University Campina Grande (CCTA-UFCG) in the city of Pombal, PB, Brazil. Pombal is located at $6^{\circ} 47^{\prime} 05.1^{\prime \prime} \mathrm{S}$ $37^{\circ} 48^{\prime} 06.3^{\prime \prime} \mathrm{W}$, having a climate of the type tropical semi-arid, with summer (February to March) rains, in agreement with Silva et al. (2011).

For obtaining the seeds, we cut in the middle the fruits of fisális, at complete maturation stage, using a bistoury and the seeds were extracted manually. The fruits were washed in running water using a thin mesh sieve for the complete removal of the mucilage. The seeds were after dried in atmosphere conditions for three days on two leaves of paper towel. Before the experiment, all seeds were treated with hypochlorite at $2 \%$ during five minutes.

\subsection{The Experiment}

We used a completely randomized design in a factorial $2 \times 3$ experiment that corresponded to two containers and three substrates. The two treatments of containers were: polypropylene tray of 200 cells (C1) and containers of polypropylene of $50 \mathrm{~mL}(\mathrm{C} 2)$. The substrates were: commercial Hortiplant ${ }^{\circledR}(\mathrm{S} 1)$, and ravine soil + fine sand + source of organic matter (organic compost) in the proportions of 2:1:1 and 2:1:2 (S2 and S3, respectively). Four replicates with 25 seeds were used by treatment. 
The commercial substrate (Hortiplant ${ }^{\circledR}$ ) was composed by pinus peel, manure, sawdust, peel coconut fiber, vermiculite, and peel of rice, ash, agricultural plaster, carbonate of calcium, magnesium, and addictive (fertilizing). The physical and chemical compositions of the commercial substrate and the alternative substrate are presented in Table 1.

Table 1. Physical and chemical composition of the substrates used in the production of seedlings of Physalis peruviana L. Pombal-PB, UFCG 2018

\begin{tabular}{|c|c|c|c|c|c|c|c|c|}
\hline & $\mathrm{pH}$ & $\mathrm{P}$ & $\mathrm{S}-\mathrm{SO}^{-2}$ & $\mathrm{~K}^{+}$ & $\mathrm{Na}^{+}$ & $\mathrm{H}^{+}+\mathrm{Al}^{+3}$ & $\mathrm{Al}^{+3}$ & $\mathrm{Ca}^{+2}$ \\
\hline & Water $(1: 2.5)$ & \multicolumn{3}{|c|}{---------------- $\mathrm{mg} \mathrm{dm} \mathrm{dm}^{-3}$-------------- } & \multicolumn{4}{|c|}{ 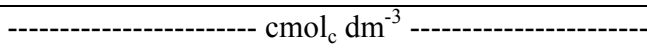 } \\
\hline S1 & 5.5 & 257.30 & - & 785.10 & 0.43 & 8.57 & 0.05 & 2.69 \\
\hline S2 & 7.5 & 467.10 & - & 607.68 & 1.33 & 0.00 & 0.00 & 1.16 \\
\hline \multirow[t]{3}{*}{ S3 } & 7.7 & 526.28 & - & 761.44 & 0.54 & 0.00 & 0.00 & 1.25 \\
\hline & $\mathrm{Mg}^{+2}$ & SB & $\mathrm{CCC}$ & M.O. & Sand & Silt & Clay & Texture class \\
\hline & \multicolumn{7}{|c|}{----------- $\mathrm{cmol}_{\mathrm{c}} \mathrm{dm}^{-3}$--------- } & \\
\hline $\mathrm{S} 1$ & 1.46 & 6.60 & 16.17 & 233.51 & 878 & 113 & 9 & - \\
\hline S2 & 1.06 & 5.11 & 5.11 & 3.58 & 780 & 191 & 29 & Sandy France \\
\hline S3 & 0.41 & 4.15 & 4.15 & 11.88 & 809 & 176 & 15 & Sandy France \\
\hline
\end{tabular}

Note. SB: Sum of Exchangeable Bases; CCC: Cation Change Capacity; M.O.: Organic Matter.

S1: commercial substrate Hortiplant ${ }^{\mathbb{B}}$; S2 and S3: ravine soil + sand dies + source of organic matter in the proportions $2: 1: 1$ and $2: 1: 2$, respectively.

The substrates S2 and S3 were prepared through manual homogenization and distributed in the containers. The seeds were sowed at a depth of $0.5 \mathrm{~cm}$. The irrigation was realized using manual watering in an amount suitable to the culture.

The variables analyzed were percentage of emergency (PE) and emergency speed index (ESI) of the plants, height of the plants (PH), the number of leaves (NL), length of the main root (LMR), and wet and dry mass of the root (RWM and MDR, respectively) and the aerial part (APWM and APDR, respectively) at the 30 days after sowing.

The counting of the emerged seedlings started in the 5th day after the sowing (DAS) until the 28th day (Brazil, 2009). For counting, were considered those seedlings that presented the two cotyledons emerged and wholly expanded. The emergency of seedlings (ES) and the emergency velocity index (EVI) of seedlings were determined following Maguire (1962). The plant height (PH) was measured from the apex of the plant to the root using a graduate ruler in centimeters. The number of leaves (NL) was obtained by counting the developed leaves. For the evaluation of the dry mass of the root and the aerial part, the seedlings were separated into aerial part and roots and conditioned in paper bags. The material was dried in a forced air circulation oven at $65{ }^{\circ} \mathrm{C}$ until it reaches a constant weight. The wet and dry material were weighed in analytical balances ( $0.001 \mathrm{~g}$ of precision), and the values expressed in g plantule $^{-1}$ (Sampaio, Ramos, Guilherme, Costa, \& Fernandes, 2008).

\subsection{Statistical Analysis}

Analysis of Variance were used to test the effects of the substrate and the container on the variables measured, and the averages of each treatment were compared by the Tukey's test at the level of 5\% of probability. All analyses were performed at the statistical program SISVAR 5.3 (Ferreira, 2011).

\section{Results and Discussion}

\subsection{Analysis of Containers $\times$ Substrate}

We found a significant interaction between the factors substrate and containers for most of the studied variables, except for the length of the main root of P. peruviana L. plants (Table 2). The type of substrate had a significant effect on all variables, including the length of the main root. Moreover, the type of containers did not affect the number of leaves and the length of main root (Table 2). 
Table 2. Results of the Analysis of variance (medium square) of the percentage of emergency (PE), index of emergency speed (ESI), height of the plant (PH), number of leaves (NL), length of the main root (LMR), wet mass of the aerial part (APWM), wet mass of the root (RWM), mass dries of the aerial part (APDM) and mass dries of the root (RDM) per plant of Physalis peruviana L. formed in different substrates (S) and containers (C) in the production of seedlings. Pombal-PB, UFCG, 2018

\begin{tabular}{lllllllllll}
\hline & DF & PE & ESI & PH & NL & LMR & APWM & APDM & RWM & RDM \\
\hline $\mathrm{S}$ & 2 & $6178.17^{* *}$ & $10.56^{* *}$ & $0.29^{* *}$ & $2.16^{* *}$ & $14.80^{* *}$ & $0.08^{* *}$ & $0.0008^{* *}$ & $0.07^{* *}$ & $0.0006^{* *}$ \\
$\mathrm{C}$ & 1 & $1320.17^{* *}$ & $0.594^{*}$ & $0.35^{* *}$ & $0.14 \mathrm{~ns}$ & $0.90 \mathrm{~ns}$ & $0.04^{* *}$ & $0.0003^{* *}$ & $0.03^{* *}$ & $0.0006^{* *}$ \\
$\mathrm{~S} \times \mathrm{C}$ & 2 & $738.17^{* *}$ & $0.55^{*}$ & $0.30^{* *}$ & $1.97^{* *}$ & $2.60 \mathrm{~ns}$ & $0.07^{* *}$ & $0.0007^{* *}$ & $0.04^{* *}$ & $0.0004^{* *}$ \\
\hdashline $\begin{array}{l}\text { Residue } \\
\text { Total }\end{array}$ & 18 & 37.94 & 0.09 & 0.01 & 0.13 & 1.04 & 0.001 & $210^{-5}$ & 0.001 & $3.410^{-5}$ \\
$\mathrm{CV} \%$ & & & & & & & & & & \\
\hline
\end{tabular}

Note. ns, ${ }^{* *}$ and $*$ refers to: no significant, significant to $1 \%$ and $5 \%$, respectively, for the test $\mathrm{F}$. DF $=$ Degree of freedom.

The use of the commercial substrate in the production of seedlings of P. peruviana L. favored a larger number of plants in a lower time, confirmed by the percentage of emergency and the emergency speed index of seedlings, independent of the used container (Table 3). These results can be related to the aeration characteristics, organic matter content and capacity of water retention of the commercial substrate, according to Table 1 .

Table 3. Average values and results of the Tukey's test for the variables of the percentage of emergency (PE), index of emergency speed (ESI), height of the plant (PH), number of leaves (NL), length of the main root (LMR), wet mass of the aerial part (APWM), wet mass of the root (RWM), mass dries of the aerial part (APDM) and mass dries of the root (RDM) per plant of Physalis peruviana L. formed in different substrates (S) and containers (C) in the production of seedlings. Pombal-PB, UFCG, 2018

\begin{tabular}{|c|c|c|c|c|c|c|}
\hline \multirow{3}{*}{ Substrate } & \multicolumn{6}{|c|}{ Containers } \\
\hline & \multicolumn{2}{|c|}{ PE (\%) } & \multicolumn{2}{|c|}{ ESI } & \multicolumn{2}{|c|}{$\mathrm{PH}(\mathrm{cm})$} \\
\hline & $\mathrm{C} 1$ & $\mathrm{C} 2$ & $\mathrm{C} 1$ & $\mathrm{C} 1$ & $\mathrm{C} 2$ & $\mathrm{C} 1$ \\
\hline S1 & $90.00 \mathrm{Aa}$ & $87.00 \mathrm{Aa}$ & $2.93 \mathrm{Aa}$ & $90.00 \mathrm{Aa}$ & $87.00 \mathrm{Aa}$ & $2.93 \mathrm{Aa}$ \\
\hline $\mathrm{S} 2$ & $62.00 \mathrm{Ba}$ & $25.00 \mathrm{Bb}$ & $1.55 \mathrm{Ba}$ & $62.00 \mathrm{Ba}$ & $25.00 \mathrm{Bb}$ & $1.55 \mathrm{Ba}$ \\
\hline S3 & $40.00 \mathrm{Ca}$ & $35.00 \mathrm{Ba}$ & $0.80 \mathrm{Ca}$ & $40.00 \mathrm{Ca}$ & $35.00 \mathrm{Ba}$ & $0.80 \mathrm{Ca}$ \\
\hline \multirow{2}{*}{ Substrate } & \multicolumn{2}{|c|}{$\mathrm{NL}$} & \multicolumn{2}{|c|}{$\operatorname{LMR}(\mathrm{cm})$} & \multicolumn{2}{|c|}{ APWM $\left(\right.$ g plant $\left.^{-1}\right)$} \\
\hline & $\mathrm{C} 1$ & $\mathrm{C} 2$ & $\mathrm{C} 1$ & $\mathrm{C} 1$ & $\mathrm{C} 2$ & $\mathrm{C} 1$ \\
\hline S1 & $4 \mathrm{Aa}$ & $5 \mathrm{Aa}$ & $6.28 \mathrm{Aa}$ & $4 \mathrm{Aa}$ & $5 \mathrm{Aa}$ & $6.28 \mathrm{Aa}$ \\
\hline S2 & $3 \mathrm{Aa}$ & $3 \mathrm{Ba}$ & $5.12 \mathrm{Aa}$ & $3 \mathrm{Aa}$ & $3 \mathrm{Ba}$ & $5.12 \mathrm{Aa}$ \\
\hline S3 & $4 \mathrm{Aa}$ & $3 \mathrm{Bb}$ & $4.73 \mathrm{Aa}$ & $4 \mathrm{Aa}$ & $3 \mathrm{Bb}$ & $4.73 \mathrm{Aa}$ \\
\hline \multirow{2}{*}{ Substrate } & \multicolumn{2}{|c|}{ RWM $\left(\right.$ g planta $\left.^{-1}\right)$} & \multicolumn{2}{|c|}{ APDM $\left(\right.$ g planta $\left.^{-1}\right)$} & \multicolumn{2}{|c|}{ RDM $\left(\right.$ g planta $\left.^{-1}\right)$} \\
\hline & $\mathrm{C} 1$ & $\mathrm{C} 2$ & $\mathrm{C} 1$ & $\mathrm{C} 1$ & $\mathrm{C} 2$ & $\mathrm{C} 1$ \\
\hline S1 & $0.12 \mathrm{Ab}$ & $0.34 \mathrm{Aa}$ & $0.01 \mathrm{Ab}$ & $0.12 \mathrm{Ab}$ & $0.34 \mathrm{Aa}$ & $0.01 \mathrm{Ab}$ \\
\hline S2 & $0.06 \mathrm{Aa}$ & $0.09 \mathrm{Ba}$ & $0.01 \mathrm{Aa}$ & $0.06 \mathrm{Aa}$ & $0.09 \mathrm{Ba}$ & $0.01 \mathrm{Aa}$ \\
\hline S3 & $0.08 \mathrm{Aa}$ & $0.03 \mathrm{Ba}$ & $0.01 \mathrm{Aa}$ & $0.08 \mathrm{Aa}$ & $0.03 \mathrm{Ba}$ & $0.01 \mathrm{Aa}$ \\
\hline
\end{tabular}

Note. For each variable, capital letters refers to the difference among substrate (columns), and lower case letters refers to the difference among containers (lines), using the test Tukey to $5 \%$ of probability $(\mathrm{p}<005)$.

The composition of the commercial substrate tends to guarantee high porosity and low density, which can facilitate the seedling to emerge (Dousseau, Alvarenga, Arantes, Oliveira, \& Nery, 2008). However, the size of the seed, the demands regarding the moisture, sensibility or not to the light and the easiness that the commercial substrate offers for the growth and evaluation of the plants also should be taken into account. França, Leite, Nascimento, and Oliveira, (2015) observed similar results of larger germination and emergency speed index using commercial substrate into Physalis angulata L., at Feira de Santana, BA, northeast of Brazil. 
The substrates S2 and S3 presented a reduction of up to 50\% in the percentage of emergency speed of emergency index of P. peruviana L. (Table 3). The lower performance can be a consequence of the characteristics related to the $\mathrm{pH}$ higher than 7.5, associated to the inferior organic matter content and low cation change capacity (Table 1), leading to the smallest availability of nutrients for the plant growth. Fischer, Miranda, Piedrahita, and Romero (2005), highlight that the soils recommended for the culture are those which present granular structure, sandy-clay, with a high content of organic matter and $\mathrm{pH}$ between 5.5 and 6.8 .

The seedlings of P. peruviana L. presented larger height when developed in a container of polypropylene of 50 $\mathrm{mL}(\mathrm{C} 2)$ using the commercial substrate (S1) (Table 3). The use of this substrate still guaranteed a most significant number of leaves ( 5 leaves per plant) and the largest length of the main root $(7.79 \mathrm{~cm}$ per plant), despite these variables do not differ between the types of employed container. Therefore, these characteristics associated to the seedling during the establishment, guarantee a better fixation in the substrate and exploration of the nutrients by the root system, a broad photosynthetic efficiency in function of the number of leaves, reflecting in the better general quality of the seedlings.

Ferreira, Moreira, Santos, Delfim, and Costa, (2011) observed that commercial organic substrate Mecplant ${ }^{\circledR}$ guaranteed the production of quality seedlings with 4.15 leaves per plant of Physalis sp. Bagatim (2017) did not find effects of the commercial substrate on the medium length of the root and the aerial part of Physalis angulata L. However, Bagatim (2017) found the best growth of the root system and the aerial part in the presence of the commercial substrate based on pinus peel, guaranteeing a larger number of leaves and consequently, a larger photosynthetic area for the seedling, resulting in a better quality.

Costa, Andrade, Rocha, Souza, and Flávio Neto (2009) when using different proportions of coconut fiber, peel of charred rice and vermiculita as substrate in the cucumber cultivation didn't observe significant effect for the variable height of plants up to the 75 DAS.

\subsection{Analysis of Wet and Dry Mass of Plants}

We found higher values of wet and dry mass of the aerial part and of the root produced in the commercial substrate (S1) using the container of polypropylene of $50 \mathrm{~mL}$ (C2) (Table 3). The architecture of the aerial part, larger height of plants, larger number of leaves, and length of roots produced in those substrate and container, explain the efficient accumulation of biomass of both the aerial part and the root system of $P$. peruviana $\mathrm{L}$. These characteristics ensure better nutrition, absorption of water and larger area of light reception with consequent higher photosynthetic rates, which, according to Negreiros, Braga, Álvares \& Bruckner (2004), makes biometric aspects, as the biomass, increase considerably.

The container of polypropylene of $50 \mathrm{~mL}$ overcame the container of trays of 200 cells, when associated to the commercial substrate Hortplant $^{\circledR}$, showing better values for most of the analyzed variables during the production of seedlings of Physalis peruviana L. The excellent performance of the seedlings produced in that container is a consequence of the available space for the growth of roots and translocation of photo-assimilates of the aerial part, resulting in seedlings ready for transplantation at the 28 days after sowing. Tanan (2015) sowing Physalis spp. in trays of polystyrene expanded with 128 cells and using the commercial substrate Biomix ${ }^{\circledR}$ verified that the plants were only capable for the transplant between 28 to the 32 days after the sowing, similar to which was observed in the present experiment. According to Guimarães, Echer, and Minami (2002) containers with low availability of space for roots, hinder the supply of production factors that guarantee the healthy growth of the seedlings.

\section{Conclusion}

The commercial substrate Hortplant ${ }^{\circledR}$ associated with the use of the container of polypropylene of $50 \mathrm{~mL}$ provided larger emergency of seedlings, and growth of the aerial part and root systems of Physalis peruviana L.

\section{References}

Bagatim, A. C. (2017). Temperatura e substrato na germinação de Physalis angulata L. [p. 33, Dissertação (Mestrado em Agronomia-Produção vegetal), Universidade Estadual Paulista, Jaboticabal, SP, Brazil]. Retrieved from https://repositorio.unesp.br/handle/11449/150341

Bardiviesso, E. M., Costa, E., Barcelos, M. N., Bardiviesso, D. M., \& Murakami, L. F. (2014). Crescimento de berinjela verde em diferentes substratos. Revista de Agricultura Neotropical, 1(1), 17-25.

Brasil. (2009). Regras para Análise de Sementes (p. 399). Brasília: MAPA (Ministério da Agricultura, Pecuária e Abastecimento)/ACS. 
Coêlho, J. L. S., Silva, R. M., Baima, W. D. S., Gonçalves, H. R. O., França Neto, C. S., \& Aguiar, A. V. M. (2013). Diferentes substratos na produção de mudas de pimentão. Revista ACSA, 9(2), 01-04.

Costa, L. M., Andrade, J. W. S., Rocha, A. C., Souza, L. P., \& Flávio Neto, J. (2009). Avaliação de diferentes substratos para o cultivo de pepino (Cucumis sativus L.). Global Science and Technology, 2(2), 21-26.

Dousseau, S., Alvarenga, A. A., Arantes, L. O., Oliveira, D. M., \& Nery, F. C. (2008). Germinação de sementes de tanchagem (Plantago tomentosa Lam.): Influência da temperatura, luz e substrato. Ciência e Agrotecnologia, 32(2), 438-443. https://doi.org/10.1590/S1413-70542008000200014

Ferreira, D. F. (2011). Sisvar-Software: Versão 5.3. Lavras: UFLA/DEX, Software.

Ferreira, L. V., Moreira, R. M., Santos, A. C. M. M., Delfim, T. F., \& Costa, L. C. (2011). Germinação e desenvolvimento inicial de Physalis sp. em diferentes substratos e fotoperiodos. Anais ... XIII Encontro de Pós-graduação UFPEL, Pelotas, Brazil.

Filgueira, F. A. R. (2013). Novo manual de olericultura: Agrotecnologia moderna na produção e comercialização de hortaliças (3rd ed., p. 421). Viçosa-MG: UFV.

Fischer, G., Almanza-Merchán, P. J., \& Miranda, D. (2014). Importancia y cultivo de la uchuva (Physalis peruviana L.). Revista Brasileira de Fruticultura, 36(1), 1-15. https://doi.org/10.1590/0100-2945-441/13

Fischer, G., Miranda, D., Piedrahita, W., \& Romero, J. (2005). Avances en cultivo, poscosecha y exportación de (Physalis peruviana L.) en Colombia (1st ed., p. 222). Bogotá: Universidad Nacional de Colombia, Faculdad de Agronomía.

França, V. C., Leite, R. S., Nascimento, M. N., \& Oliveira, L. M. (2015). Germinação de sementes de Physalis angulata em diferentes substratos em casa de vegetação. II Simpósio da Rede de Recursos Genéticos Vegetais do Nordeste, 2015, Fortaleza. Anais do II Simpósio da RGV Nordeste. Fortaleza, Embrapa Agroindústria Tropical.

Guimarães, V. F., Echer, M. M., \& Minami, K. (2002). Métodos de produção de mudas, distribuição de matéria seca produtividade de plântulas de beterraba. Horticultura Brasileira, 20(3), 505-509. https://doi.org/ 10.1590/S0102-05362002000300022

Lima, C. S. M. Galarça, S. P., Betemps, D. L., Rufato, A. R., \& Rufato, L. (2012). Avaliação física, química e fitoquímica de frutos de Physalis, ao longo do período de colheita. Revista Brasileira de Fruticultura, 34(4), 1004-1012. https://doi.org/10.1590/S0100-29452012000400006

Lima, C. S. M., Gonçalves, M. A., Tomaz, Z. F. P., Rufato, A. R., \& Fachinello, J. C. (2010a). Sistemas de tutoramento e épocas de transplante de Physalis. Ciência Rural, 40(12), 2472-2479. https://doi.org/10.1590/ S0103-84782010001200006

Lima, C. S. M., Vilanova, D. S., Gonçalves, M. A., Rufato, L., \& Rufato, A. D. R. (2010b). Diferentes substratos e recipientes na formação de mudas de Physalis peruviana L. (pp. 180-181). V Simpósio Nacional do Morango e IV Encontro Sobre Pequenas Frutas e Frutas Nativas do Mercosul, 2010, Pelotas. Anais... Pelotas-RS, Brazil.

Lima, R. L. S., Severino, M. A., Tomaz, Z. F. P., Rufato, A. R., \& Fachinello, J. C. (2006). Volume de recipientes e composição de substratos para produção de mudas de mamoneira. Ciência e Agrotecnologia, 30(3), 480-486. https://doi.org/10.1590/S1413-70542006000300014

Lorenzi, H., \& Matos, F. J. A. (2008). Plantas Medicinais no Brasil: Nativas e exóticas cultivadas (2nd ed., p. 544). Nova Odessa, São Paulo: Instituto Plantarum.

Maciel, P. H. F. Z. A., Rocha, D. S., Paro, P., Gioda, M., \& Botrel, M. C. G. (2007). Produção de mudas de Jatropha curcas L. em diferentes substratos. Congresso da Academia Trinacional de Ciências, 2. Mostra de Trabalhos e Protótipos, 2. Workshop do PDTA-Programa de Desenvolvimento Tecnológico 25 Avançado, 2. Foz do Iguaçu-PR. Resumos... Foz do Iguaçu-PR: Universidade Estadual do Oeste do Paraná (UNIOESTE).

Maguire, J. D. (1962). Speed of germination-aid in selection and evaluation for seedling emergence and vigor. Crop Science, 2(1), 176-177. https://doi.org/10.2135/cropsci1962.0011183X000200020033x

Menezes Júnior, F. O. G., Fernandes, H. S., Mauch, C. R., \& Silva, J. B. (2000). Caracterização de diferentes substratos e seu desempenho na produção de mudas de alface em ambiente protegido. Horticultura Brasileira, 18(3), 164-170. https://doi.org/10.1590/S0102-05362000000300004 
Negreiros, J. R. S., Braga, L. R., Álvares, V. S., \& Bruckner, C. H. (2004). Influência de substratos na formação de porta-enxerto de gravioleira (Annona muricata L.). Ciência e Agrotecnologia, 28(3), 530-536. https://doi.org/10.1590/S1413-70542004000300007

Novoa, R. M., Bojacá, J., Galvis, Y., \& Fischer, G. (2006). La madurez del fruto y el secado del cáliz influyen en el comportamiento poscosecha de la uchuva (Physalis peruviana L.) almacenada. Agronomía Colombiana, 24(1), 77-86.

Paiva, E. P., Maia, S. S. S., Cunha, C. S. M., Coelho, M. F. B., \& Silva, F. N. (2011). Composição do substrato para o desenvolvimento de mudas de manjericão (Ocimum basilicum L.). Revista Caatinga, 24(4), 62-67.

Pinto, E. O. S. (2006). Germinação de sementes, enraizamento de estacas caulinares e cultivo in vitro de cubiu (Solanum sessiliflorum Dunal.) [51f., Tese (Doutorado em Agronomia), UNESP]. Retrieved from https://repositorio.unesp.br/handle/11449/103275

Rodrigues, F. A., Penoni, E. S., Soares, J. D. R., \& Pasqual, M. (2012). Caracterização do ponto de colheita de Physalis peruviana L. na região de Lavras, MG. Bioscience Journal, 28(6), 862-867.

Rufato, L., Rufato, A. D. R., Schlemper, C., Lima, C. S. M., \& Kretzschmar, A. A. (2008). Aspectos técnicos da cultura da Physalis (p. 101). Pelotas: UDESC.

Sampaio, R. A., Ramos, S. J., Guilherme, D. O., Costa, C. A., \& Fernandes, L. A. (2008). Produção de mudas de tomateiro em substratos contendo fibra de coco e pó de rocha. Horticultura Brasileira, 26(4), 499-503. https://doi.org/10.1590/S0102-05362008000400015

Schiavo, J. A., \& Martins, M. A. (2003). Produção de mudas de acácia colonizadas com micorrizas e rizóbio em diferentes recipientes. Pesquisa Agropecuária Brasileira, 38(2), 173-178. https://doi.org/10.1590/S0100204X2003000200002

Silva, P. H. M., \& Stein, L. M. (2008). Produção de mudas e recomendações de adubação no viveiro. Piracicaba: IPEF. Retrieved from http://www.ipef.br/silvicultura/producaomudas.asp

Silva, V. P. R., Pereira, E. R. R., Azevedo, P. V., Sousa, F. A. S., \& Sousa, I. F. (2011). Análise da pluviometria e dias chuvosos na região Nordeste do Brasil. Revista Brasileira de Engenharia Agricola e Ambiental, 15(2), 131-138. https://doi.org/10.1590/S1415-43662011000200004

Tanan, T. T. (2015). Fenologia e caracterização dos frutos de espécies de Physalis cultivadas no semiárido Baiano [58f., Cap. 2, Dissertação (Mestrado), Recursos Genéticos Vegetais, Departamento de Recursos Genéticos Vegetais, Universidade Estadual de Feira de Santana, BA, UEFS]. Retrieved from http://tede2.uefs.br:8080/handle/tede/156

Viana, J. S., Gonçalvez, E. P., Andrade, L. A., Oliveira, L. S. B., \& Silva, E. O. (2008). Crescimento de mudas de Bauhinia forficata Link. em diferentes tamanhos de recipientes. Floresta, 38(4), 663-671. https://doi.org/ 10.5380/rf.v38i4.13161

\section{Copyrights}

Copyright for this article is retained by the author (s), with first publication rights granted to the journal.

This is an open-access article distributed under the terms and conditions of the Creative Commons Attribution license (http://creativecommons.org/licenses/by/4.0/). 